\title{
Development of Porcine Embryos Reconstructed by Nuclear Transfer of Cultured Cumulus Cells into In Vitro Matured and Enucleated Oocytes
}

\author{
Yinzhong BING ${ }^{1)}$, Limei $\mathrm{CHE}^{1)}$, Yuji HIRAO ${ }^{1)}$, Naoki TAKENOUCHI') and \\ Takashi NAGAI)\# \\ ${ }^{1)}$ Department of Animal Production, Tohoku National Agricultural Experiment Station, \\ Morioka, Iwate 020-0198, Japan \\ Present: " Department of Animal Reproduction, National Institute of Animal Industry, Tsukuba, \\ Ibaraki 305-0091, Japan
}

\begin{abstract}
This was a study on the developmental ability of porcine embryos reconstructed by microinjection of a nucleus of cultured (non-starving culture) cumulus cells directly into the cytoplasm of oocytes matured and enucleated in vitro. Cumulus-oocyte complexes (COCs) derived from slaughterhouse ovaries were matured for $22 \mathrm{~h}$ in a modified NCSU23 (mNCSU23) medium supplemented with pFF, cysteine, PMSG, hCG and EGF, and then for another $22 \mathrm{~h}$ in the same medium without the hormones. In the meantime, cumulus cells were freed from some COCs and cultured in MEM supplemented with $10 \%$ FCS. After $44 \mathrm{~h}$ of culture, the smaller cumulus cells (10-12 $\mu \mathrm{m})$ were injected directly into the cystoplasm of enucleated oocytes. The cell membrane of cumulus cells was broken mechanically prior to the injection. After incubation for $30 \mathrm{~min}$ in mNCSU23 supplemented with $4 \mathrm{mg} / \mathrm{ml}$ BSA and $0.1 \mathrm{mg} / \mathrm{ml}$ cysteine, reconstructed oocytes were activated by exposure to $200 \mu \mathrm{M}$ thimerosal for $10 \mathrm{~min}$ followed by incubation in $8 \mathrm{mM}$ dithiothreitol for $30 \mathrm{~min}$. Oocytes with an intact plasma membrane were then cultured in mNCSU23 supplemented with BSA. The development of reconstructed embryos and the number of nuclei in them were monitored after 48 $\mathrm{h}$ and 6 days of culture. As a control group, oocytes were activated parthenogenetically and cultured as described above. The percentage of cleavage in the nuclear transfer (NT) group after $48 \mathrm{~h}$ of activation was significantly lower than that in the control group ( $36.4 \%$ vs $83.7 \%, \mathrm{P}<0.05$ ), but the rates of blastocyst were similar in the NT and control groups (5.5\% vs $10.9 \%)$. The mean numbers of cells in a blastocyst were 19.3 and 30.3 for NT and control groups, respectively. These results indicate that the reconstructed embryos prepared in the system described can develop to the blastocyst stage.

Key words: Nuclear transfer, Cumulus cell, Micromanipulation, Oocyte activation, Reconstructed porcine embryo.
\end{abstract}

(J. Reprod. Dev. 46: 375-379, 2000)

$\mathbf{P}$ roduction of cloned offspring by nuclear transfer from cultured somatic cells has been successfully achieved in sheep [1], cattle [2-6], goats [7] and mice [8]. Only a few papers that describe the development of reconstructed

Accepted for publication: August 23, 2000

Correspondence: T. Nagai embryos to the blastocyst stage in pigs have been published [9-12], but the porcine somatic cell nuclear transfer technique is potentially effective with specific genetic modifications for xenotransplantation and human medicine.

There are two main methods for nuclear transfer in mammals. Most cloned offspring obtained so far 
have been derived from embryos reconstructed by cell fusion as a method of nuclear transfer [1-6]. Another is to inject the nucleus directly into the cytoplasm of oocytes, as developed in mice [8, 13]. As the donor cells, cumulus cells not only have a high developmental potential after nuclear transfer in cattle and mice, resulting in the birth of live offspring $[3,5,13]$, but also can easily be obtained from slaughterhouse ovaries, but there is little information on the appropriateness of using them in pigs. The present study was designed to evaluate the rates of development of pig embryos reconstructed by microinjection of cultured cumulus cells (non-starved) into matured and enucleated oocytes in vitro.

\section{Materials and Methods}

In vitro maturation (IVM) of porcine oocytes

Porcine oocytes with compact cumulus cell complexes (COCs) were collected from follicles (3$5 \mathrm{~mm}$ in diameter) by means of an 18-g needle and a syringe. The COCs were selected and washed twice with modified Tyrode's solution (TALPHepes) containing $0.1 \%(\mathrm{w}: \mathrm{v})$ polyvinyl alcohol (Sigma, St. Louis, MO, U.S.A.) and twice with the final maturation medium described below. Twenty COCs were matured in microdrops $(500 \mu \mathrm{l})$ of modified NCSU23 (mNCSU23) medium supplemented with $10 \%$ porcine follicular fluid (pFF), $0.1 \mathrm{mg} / \mathrm{ml}$ cysteine (Sigma), $10 \mathrm{IU} / \mathrm{ml}$ pregnant mare's serum gonadotropin (PMSG, Serotropin; Teikoku Zouki, Tokyo, Japan), 10 IU/ $\mathrm{ml}$ human chorionic gonadotropin (hCG, Gonatropin; Teikoku Zouki) and $10 \mathrm{ng} / \mathrm{ml}$ epidermal growth factor (EGF, Sigma) covered with paraffin oil (Nakarai, Kyoto, Japan). After 22 $\mathrm{h}$ of culture, the COCs were transferred into medium of the same composition without hormone, and cultured for an additional $22 \mathrm{~h}$. All incubations were carried out at $38.5 \mathrm{C}$ in an incubator with standard humidity and $5 \% \mathrm{CO}_{2}$ in air.

\section{Preparation of cumulus cells}

Porcine cumulus cells were collected by mechanically removing cells from COCs with a small-bore pipette, and cultured for $44 \mathrm{~h}$ in MEM (Gibco-BRL, Grand Island, NY, USA) supplemented with $10 \%$ fetal calf serum (FCS,
Biocell, Carson, CA, USA). Immediately before injection, a single cell suspension of cumulus cells was prepared by standard trypsinization. The donor cells for nuclear transfer were selected by the shape (smooth edge) and size (10-12 $\mu \mathrm{m}$ in diameter). The cells were then pelleted and resuspended in calcium free TALP-Hepes supplemented with $4 \mathrm{mg} / \mathrm{ml}$ BSA (Fraction V, Sigma), and kept in this solution at room temperature until injection.

\section{Micromanipulation}

Micromanipulation was conducted as described elsewhere [12]. Briefly, after maturation culture expanded cumulus cells were removed by means of a narrow pipette after the addition of $0.25 \%$ hyaluronidase (Sigma). The matured oocytes were transferred to TALP-Hepes containing $4 \mathrm{mg} / \mathrm{ml}$ BSA and $5 \mu \mathrm{g} / \mathrm{ml}$ cytochalasin B (CB, Sigma), and enucleation was accomplished by aspirating the first polar body and the metaphase II plate with a small amount of cytoplasm by means of a piezomicropipette-driving unit. For some oocytes, confirmation of successful enucleation was achieved by staining enucleated oocytes with $5 \mu \mathrm{g} /$ $\mathrm{ml}$ Hoechst 33342 in TALP-Hepes for 20-25 min and visualizing the karyoplast under ultraviolet light. After enucleation, the oocytes were transferred to CB-free mNCSU23 supplemented with $4 \mathrm{mg} / \mathrm{ml} \mathrm{BSA}$ and $0.1 \mathrm{mg} / \mathrm{ml}$ cysteine. They were incubated for $2 \mathrm{~h}$ at $38.5 \mathrm{C}$ in a humidified atmosphere containing $5 \% \mathrm{CO}_{2}$ in air and then transferred to the microinjection chamber on the microscope stage. On this transfer, cumulus cells were prepared for injection [Fig. 1 (a),(b)]. The plasma membrane of the cumulus cells was broken by injecting a pipette $8-9 \mu \mathrm{m}$ in diameter. The visible cytoplasmic materials were removed from the cumulus cells by aspirating the cells in and out of the injection pipette. The nucleus and remaining cellular debris of cumulus cells were injected into the cytoplasm of enucleated oocytes. Care was taken to inject each cell into the cytoplasm with as little medium as possible.

\section{Activation}

After injection of the donor cells, reconstructed oocytes were incubated in mNCSU23 supplemented with $4 \mathrm{mg} / \mathrm{ml} \mathrm{BSA}$ and $0.1 \mathrm{mg} / \mathrm{ml}$ cysteine at $38.5 \mathrm{C}$ in a humidified atmosphere containing $5 \% \mathrm{CO}_{2}$ in air for $30 \mathrm{~min}$, and then the 

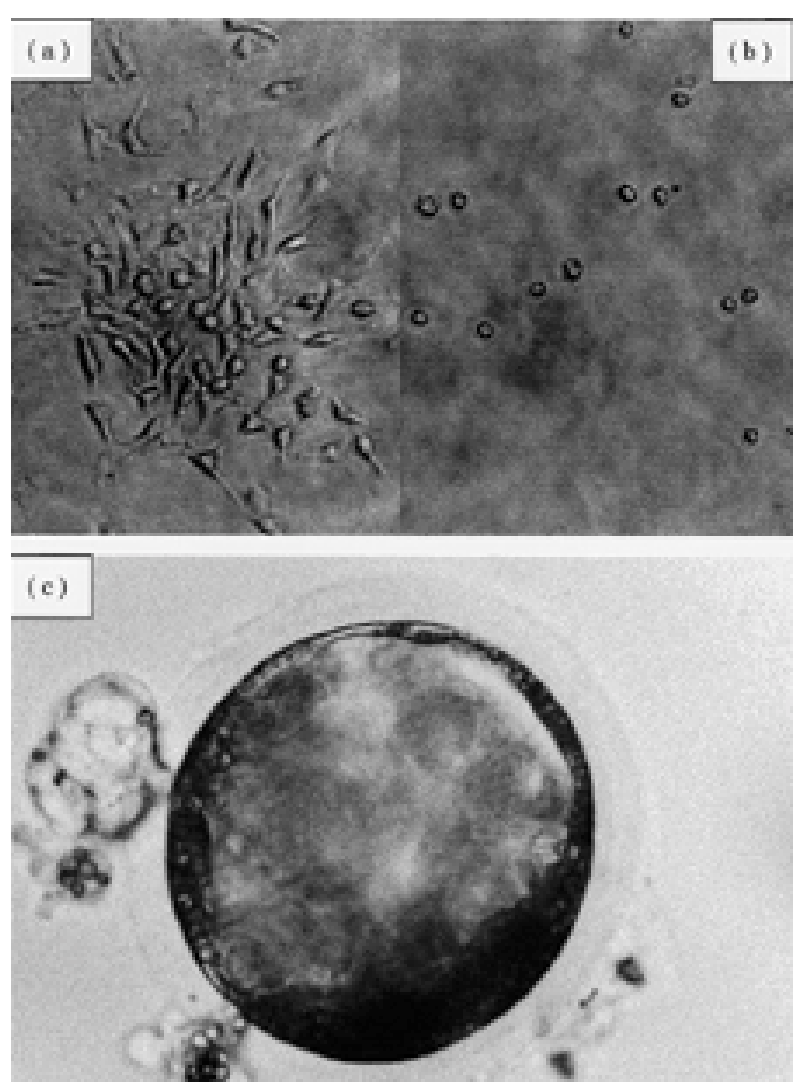

Fig. 1. (a): Cumulus cells cultured for $44 \mathrm{~h}$ in $\mathrm{MEM}+10 \%$ FCS. (b): Cumulus cells prepared by standard trypsinization before injection. (c): A blastocyst derived from nuclear transfer of a cumulus cell at 6 days of culture.

oocytes were activated by exposure to $200 \mu \mathrm{M}$ thimerosal for $10 \mathrm{~min}$, followed by incubation in mNCSU23 containing $8 \mathrm{mM}$ dithiothreitol for 30 $\min [14]$.

\section{Culture of nuclear transferred embryos and control parthenotes}

After activation, the reconstructed oocytes with an intact plasma membrane were washed 5-6 times and cultured in $20 \mu \mathrm{l}$ drops of mNCSU23 for 6 days. Some in vitro matured oocytes were simply activated parthenogenetically and cultured as described above as controls. The percentages of cleavage and development to the morulae/ blastocyst stages were examined at $48 \mathrm{~h}$ and 6 days, respectively, after activation. At the end of the culture, the number of blastocyst nuclei was counted after Hoechst 33342 epifluorescein staining.

\section{Statistical analysis}

Rates of cleavage and development to morulae/ blastocyst stages were evaluated by analysis of variance (ANOVA) and Fisher's protected least significant different test. A probability of $\mathrm{P}<0.05$ was set as a significant level.

\section{Results}

As shown in Table 1, the percentage of cleavages in the nuclear transfer (NT) group after $48 \mathrm{~h}$ of activation was significantly lower than that in the control group $(36.4 \%$ vs $83.7 \%, \mathrm{P}<0.05)$, but the morulae and blastocyst rates for the total number of oocytes used were similar ( $7.2 \%$ vs $13.0 \% ; 5.5 \%$ vs $10.9 \%$, respectively) for the NT and control groups. The mean numbers of nuclei in a blastocyst were 19.3 and 30.3 for NT and control groups, respectively. A blastocyst (the number of nuclei is 28) derived from NT of a cumulus cell at 6 days of culture is shown in Fig. 1 (c).

Table 1. Development of porcine embryos reconstructed by nuclear transfer of cultured cumulus cells into in vitro matured and enucleated oocytes

\begin{tabular}{|c|c|c|c|c|c|}
\hline \multirow[t]{2}{*}{ Treatments } & $\begin{array}{l}\text { No.of } \\
\text { oocytes }\end{array}$ & $\begin{array}{c}\text { No. }(\%) \text { of cleaved } \\
\text { oocytes }\end{array}$ & $\begin{array}{c}\text { No. }(\%) \text { of } \\
\text { morulae }\end{array}$ & $\begin{array}{l}\text { No. }(\%) \text { of } \\
\text { blastocyst }\end{array}$ & \multirow{2}{*}{$\begin{array}{r}\text { nucleus/ } \\
\text { blastocyst } \\
\text { (Range) }\end{array}$} \\
\hline & used & $48 \mathrm{~h}$ after injection & \multicolumn{2}{|c|}{6 days after injection } & \\
\hline \multirow[t]{2}{*}{ Control } & 92 & 77 & 12 & 10 & 30.3 \\
\hline & & $(83.7 \%)^{\mathrm{a}}$ & $(13.0 \%)$ & $(10.9 \%)$ & $(26-33)$ \\
\hline \multirow[t]{2}{*}{$\mathrm{NT}^{*}$} & 55 & 20 & 4 & 3 & 19.3 \\
\hline & & $(36.4 \%)^{b}$ & $(7.2 \%)$ & $(5.5 \%)$ & $(8-28)$ \\
\hline
\end{tabular}

a-b Within the same column, values with different superscripts differ $(\mathrm{P}<0.05)$.

*Nuclear transfer. 


\section{Discussion}

The present results indicate that porcine embryos reconstructed by microinjection of cultured cumulus cells directly into the cytoplasm of oocytes matured and enucleated in vitro can development to the blastocyst stage. This is consistent with the previous report on fetal fibroblast cells as donor cells [12]. Compared to the method of electric cell fusion used for "Dolly" and many cattle experiments, microinjection of donor cells into the cytoplasm of oocytes can limit the amount of cytoplasm of donor cells incorporated into the recipient cells.

In the present study, a micromanipulator with piezo-electric elements was used to inject donor cells. Owing to the small size and proper shape of the injection needle, and also to the gentle piezopulse, the system used minimized oocyte damage. In particular, the loss of ooplasm after the puncture was minimal because the piezo-driver prevented the leakage of ooplasm. Yanagida et al. [15] achieved higher survival and fertilization rates in intracytoplasmic sperm injection in human subjects by means of a piezo-driver than in those obtained by conventional injection. Kimura and Yanagimachi [16] also achieved similar results in mice. In a logical extension, a piezo-driver was also used in the nuclear transfer in mice, resulting in great success $[8,13]$.

An identified important factor which affects the success rate of somatic cell nuclear transfer is the appropriate cell cycle coordination of the donor nucleus and recipient oocytes. To maintain correct ploidy, donor nuclei in the G0/G1 phase should be transferred to metaphase II arrested oocytes with a high level of maturation promoting factor [1]. In this study, although the cell cycle phase of the donors was not identified, many of the cells were probably at G0/G1, because it was reported that small- and medium-sized cumulus cells (9-20 $\mu \mathrm{m}$ in diameter) contained nuclei at the G0/G1 phase (95-98\%) at a significantly higher rate than largesized cells $(82 \%, 20-26 \mu \mathrm{m}$ in diameter) regardless of the serum starvation and confluent cultures in cattle [17]. Recently, studies of porcine fetal fibroblasts showed that as the cell size decreased, the percentages of cells at G0 or G1 increased [18].
Therefore, in this study only the smaller (10-12 $\mu \mathrm{m}$ in diameter) cumulus cells with smooth edges derived from non-serum starved culture were selected as the donor cells. However Zakhartchenko et al. [6] indicated that nuclei of starved fibroblasts supported the development of reconstructed embryos to the blastocyst stage significantly better than non-starved fibroblasts. There is also a report that small and large mouse cumulus cells that were naturally arrested in the G0 phase seldom support the development of reconstituted embryos beyond the 8-cell stage [13], so that although there seems no doubt that appropriate synchronization of the cell cycle is important, it is still not known how to regain the totipotency of reconstructed embryos most effectively.

The major phenotypic differences expected for the reconstructed oocytes resulted from the method used in the current study and the conventional cell fusion method may be the absence or presence of parthenogenetical activation induced simultaneously with nuclear transfer. If meiotic arrest at metaphase II is maintained after the nuclear transfer, an injected nucleus can be exposed to cytoplasmic factors at metaphase II for a long time and nuclear remodeling may occur satisfactorily. In this sense, the use of a piezodriver should be advantageous. But even with piezo, the system used in this study may not be the most suitable. Oocytes cultured in vitro for $44 \mathrm{~h}$ and matured to metaphase II were activated (27-36\%) only by penetration with an injection needle twice with an interval of $2 \mathrm{~h}$ and subsequent culture for 6 $\mathrm{h}$ after the first injection with calcium-free media both for injection and culture. One-third of the oocytes were activated probably through the release of stored intracellular free calcium $\left(\mathrm{Ca}^{2+}\right)$ during micromanipulation (unpublished). Thus this activation of reconstructed oocytes with the injection of a donor cell may be a reason why the rates of cleavage and embryos developed to the blastocyst stage were low in the present study.

In conclusion, the present study demonstrates that embryos reconstructed by microinjection of a nucleus obtained from non-starved cultured cumulus cells directly into the cytoplasm of oocytes matured and enucleated in vitro are able to develop to the blastocyst stage. 


\section{Acknowledgments}

The authors wish to thank K. Kawamura and N. Nishimoto for excellent support in the experiments.
This work was supported by the Japan Science and Technology Corporation (JST) and a Grant-in-Aid (Bio Design Program) from the Ministry of Agriculture, Forestry and Fisheries (BDP-00-III-1).

\section{References}

1. Wilmut I, Schnieke AE, McWhir J, King AJ, Campbell KH. Viable offspring derived from fetal and adult mammalian cells. Nature 1997; 385: 810813.

2. Cibelli JB, Stice SL, Golueke PJ, Kane JJ, Jerry J, Blackwell C, Ponce de Leon FA, Robl JM. Cloned transgenic calves produced from nonquiescent fetal fibroblasts. Science 1998; 280: 1256-1258.

3. Kato Y, Tani T, Sotomaru Y, Kurokawa K, Kato J, Doguchi H, Yasue H, Tsunoda Y. Eight calves cloned from somatic cells of a single adult. Science 1998; 282: 2095-2098.

4. Kubota C, Yamaguchi H, Todoroki J, Mizoshita K, Tabara N, Barber M, Yang X. Six cloned calves produced from adult fibroblast cells after long-term culture. Proc Natl Acad Sci 2000; 97: 990-995.

5. Wells DN, Misica PM, Tervit HR. Production of cloned calves following nuclear transfer with cultured adult mural granulosa cells. Biol Reprod 1999; 60: 996-1005.

6. Zakhartchenko V, Durcova-Hills G, Stojkovic M, Schernthaner W, Prelle K, Steinborn R, Muller M, Brem G, Wolf E. Effects of serum starvation and recloning on the efficiency of nuclear transfer using bovine fetal fibroblasts. J Reprod Fertil 1999; 115: 325-331.

7. Baguisi A, Behboodi E, Melican DT, Pollock JS, Destrempes MM, Cammuso C, Williams JL, Nims SD, Porter CA, Midura P, Palacios MJ, Ayres SL, Denniston RS, Hayes ML, Ziomek CA, Meade HM, Godke RA, Gavin WG, Overstrom EW, Echelard Y. Production of goats by somatic cell nuclear transfer. Nature Biotech 1999; 17: 456-461.

8. Wakayama T, Yanagimachi R. Cloning of mice from adult tail-tip cells. Nature Genetics 1999; 22: 127-128.

9. Du ZT, Verma PJ, Crocker LA, Faast R, Lyons IG, Nottle MB. Development of nuclear transfer embryos using porcine fetal fibroblasts. Theriogenology 1999; 51: 201 (abstract).

10. Han YM, Koo DB, Kang YK, Choi YH, Park JS, Han SK, Son DS and Lee KK. Developmental potential of porcine embryos produced by nuclear transfer using fetal fibroblasts. Theriogenology 2000; 53: 217 (abstract).

11. Tao T, Boquest AC, Mach Z, Petersen AL, Day BN, Prather RS. Development of pig embryos by nuclear transfer of cultured fibroblast cells. Cloning 1999a; 1: 55-62.

12. Tao T, Machàty, Z, Boquest AC, Day BN, Prather RS. Development of pig embryos reconstructed by microinjection of cultured fetal fibroblast cells into in vitro matured oocytes. Anim Reprod Sci 1999b; 56: 133-141.

13. Wakayama T, Perry ACF, Zuccotti M, Johnson KR, Yanagimachi R. Full-term development of mice from enucleated oocytes injected with cumulus cell nuclei. Nature 1998; 394: 369-374.

14. Machàty $\mathrm{Z}$, Wang $\mathrm{WH}$, Day $\mathrm{BN}$, Prather RS. Complete activation of porcine oocytes induced by the sulphydryl reagent, thimerosal. Biol Reprod 1997; 57: 1123-1127.

15. Yanagida $\mathbf{K}$, Katayose $\mathbf{H}$, Yazawa H, Kimura $\mathbf{Y}$, Konnai K, Sato A. The usefulness of a piezomicromanipulator in intracytoplasmic sperm injection in human. Human Reprod 1998; 14: 448-453.

16. Kimura H, Yanagimachi R. Intracytoplasmic sperm injection in mouse. Biol Reprod 1995; 52: 709-720.

17. Mohamed SMN, Koji I, Yoshiyuki T. Bovine nuclear transfer using cumulus cells derived from serum-starved and confluent cultures. J Reprod Dev 2000; 46: 85-92.

18. Boquest AC, Day BN, Prather RS. Flow cytometric cell cycle analysis of cultured porcine fetal fibroblast cells. Biol Reprod 1999; 60: 1013-1019. 